\title{
THE ANTHROPOGENIC INUNDATED AREA "SZCZECIN" IN THE ZONE OF ACTIVE UNDERGROUND EXPLOITATION OF HARD COAL IN THE LUBLIN COAL BASIN
}

\author{
Małgorzata Ciosmak ${ }^{1}$ \\ 1 Mechanical Engineering Faculty, Lublin University of Technology, Nadbystrzycka 36 Str., 20-618 Lublin, \\ Poland, e-mail: m.ciosmak@pollub.pl
}

Received: 2016.01.15

Accepted: 2016.03.04

Published: 2016.04.01

\begin{abstract}
The investigated area lies in the geographical centre of Lublin Province. More specifically, it is located in the northern part of the Central Coal Region, between the Puchaczów-Urszulin route and the route leading through the village of Szczecin, which the investigated inundated area is named after, and between the town of Dratów and the "Bogdanka" Hard Coal Mine. The Lublin Upland, with the Lublin Coal Basin located in its centre, has one of the most valuable natural environments in Poland. There are many reserves, Poleski National Park and Natura 2000 area. The process of the intensive hard coal exploitation makes subsidence of surface as its result. The process of basin subsidence is irreversible. This paper deals with the problem of forming an anthropogenic water reservoir and its development in compliance with the policy of sustainable development and biodiversity maintenance in the face of heavy hard coal exploitation. It is suggested to use fluorides ground water to organize a health resort based on water reservoir and the described natural environment.
\end{abstract}

Keywords: environment, protected area, mining technology, inundated area.

\section{INTRODUCTION}

The term "anthropogenic" can have different meanings when used with reference to surface water, which is particularly important in the context of water in water reservoirs. Not all water reservoirs are flow reservoirs. In a non-flow reservoir, the concentration of dissolved or suspended components cannot be reduced (diluted) by flowing water, so water quality parameters in the reservoir cannot be improved. If anthropogenically polluted (after technological processing) water is allowed to enter a non-flow reservoir, then the reservoir can be described as anthropogenically polluted. If, however, wastewater is allowed to enter a flow reservoir, the water flowing into such a reservoir, the reservoir itself and the watercourse flowing out of the reservoir become anthropogenically polluted. In contrast, a totally different situation can be observed when a surface water reservoir is created as a result of anthropo- genical activity, for retention purposes or intrinsically, due to human impact on nature. Located in the centre of the Lublin Province, the region of the Lublin Coal Basin is a lake district at the same time. The terrain is characterized by a shallow groundwater table. Since mining is done there using the stroke technology, terrain depressions begin to form post-mining voids a few years following mineral extraction. This leads to the formation of anthropogenic inundated areas which then become gradually inhabited by water organisms in a natural way, while their surroundings provide a habitat for flora and fauna. The results of observations of two water reservoirs in the investigated area: the older anthropogenic "Nadrybie Reservoir" and the new "Szczecin" reservoir, both created due to the action of the same phenomena, reveal analogous models of bottom and shoreline formation as well as fauna and flora occurrence in the water and the surrounding area. Given the proximity of the two water reservoirs, the stages 
of their formation are identical. The changes are irreversible due to the permanence of terrain deformation caused by the mining technique which is applied there. In both cases, the subsidence basins are filled with both rainwater and water flowing from the adjacent areas. The available literature offers scientific publications that usually investigate the impact of diverse human activities on the already existing natural water reservoirs or retention reservoirs. Nonetheless, it is difficult to find publications about water reservoirs originated due to anthropogenic phenomena, particularly in the areas that have high environmental value and have undergone changes due to mining at the same time. This paper deals with the problem of forming an anthropogenic water reservoir and its development in compliance with the policy of sustainable development and biodiversity maintenance in the face of heavy hard coal exploitation.

\section{DESCRIPTION OF THE AREA}

\section{Location}

The investigated area lies in the geographical centre of the Lublin Province. More specifically, it is located in the northern part of the Central Coal Region, between the Puchaczów-Urszulin route and the route leading through the village of Szczecin, which the investigated inundated area is named after, and between the town of Dratow and the "Bogdanka" Hard Coal Mine. Due to the presence of dynamic terrain deformation, i.e. mining damage, there are no human settlements in the investigated area, except for an economic unit (a former state farm) in near vicinity. Nonetheless, the economic unit has no impact on the phenomena that occur there.

\section{Land cover}

The place where the terrain subsidence started due to the application of the conveyor technology formerly served as a place for grazing farm animals and growing hay for animals. It is covered with low meadow vegetation. Since the very beginning, the flood land becomes gradually inhabited by aquatic plants and coastal vegetation, such as bulrush, reed mace and reed. This vegetation occurs on the terrain that undergoes changes irrespective of human activity, therefore, it can be regarded as natural succession.

\section{Overview of the geological structure, tectonics and morphogenesis of the investigated area}

According to Dobrowolski, Harasimiuk and Brzezińska-Wójcik (2014), the topographic profile of the Lublin Upland can be attributed to early and middle Cenozoic phenomena as well as the structure of the Upper Cretaceous and Paleogene complex. This includes a series of Alpine and contemporary tectonic phenomena together with the Upper Cretaceous and Paleogene lithological diversity. The tectonics shaped the log structure and cleavage, while the lithological diversity - as the above authors claim - exerted impact on strength properties. Tectonic movements did not, however, stop, and today they can be both horizontal and vertical. In the investigated area, the vertical movements are estimated to be approx. $0.5 \mathrm{~mm}$ per year. This paper considers boreholes that illustrate the geologic profile of the investigated area and hence provide the basis for estimating the rate of subsidence and hydraulic connections between aquifers. Table 1 gives a comparison of these boreholes.

Table 1. Comparison of boreholes representative of the investigated area

\begin{tabular}{|l|c|c|c|c|c|c|c|c|}
\hline \multicolumn{1}{|c|}{ Parameter } & $\begin{array}{c}\text { Bogdanka } \\
\text { BP-4 }\end{array}$ & Lublin 20 & Lublin 15 & Lublin 4 & Lublin 19 & Lublin 3 & Lublin 5 & Lublin 2 \\
\hline Depth [m] & 755 & 1102 & 1012 & 1089 & 1122 & 1096 & 1015.5 & 1045 \\
\hline $\begin{array}{l}\text { Bottom } \\
\text { stratigraphy }\end{array}$ & Westphalian & Namurian C & Namurian C & Namurian C & Namurian C & Namurian C & Westphalian & $\begin{array}{c}\text { Upper } \\
\text { Carboniferous }\end{array}$ \\
\hline Year of drilling & 1983 & 1972 & 1986 & 1972 & 1972 & 1972 & 1972 & 1975 \\
\hline $\begin{array}{l}\text { Elevation above } \\
\text { sea level [m] }\end{array}$ & 170 & 169.82 & 169.3 & 170.98 & 172.39 & 172.26 & 172 & 175 \\
\hline $\begin{array}{l}\text { Longitude } \\
\text { [DDMMSS,SS] }\end{array}$ & 225937.88 & 230028.95 & 225806.36 & 225906.04 & 225837.48 & 225955.53 & 225855.89 & 230246.22 \\
\hline $\begin{array}{l}\text { Latitude } \\
\text { [DDMMSS,SS] }\end{array}$ & 512009.86 & 512021.62 & 511936.88 & 511953.23 & 512026.45 & 512051.63 & 511921.07 & 512041.86 \\
\hline $\begin{array}{l}\text { Administrative } \\
\text { commune }\end{array}$ & Puchaczów & Ludwin & Puchaczów & Puchaczów & Ludwin & Ludwin & Puchaczów & Puchaczów \\
\hline \begin{tabular}{l} 
GBDG number \\
\hline
\end{tabular} & 3056733 & 3056790 & 3056829 & 3056827 & 3056752 & 3056788 & 3056828 & 3056787 \\
\hline
\end{tabular}


The last item in each table with profile details is Westphalian. Found in Lublin Province, this coal-bearing formation is used for intensive hard coal mining.

\section{Hydrologic and hydrogeologic conditions}

The Łęczyńsko-Włodawskie Lake District and the grounds around the Hard Coal Mine "Bogdanka" have four main aquifers: Quaternary-Upper Cretaceous, Lower Cretaceous and Upper Jurassic as well as Carboniferous, consisting of numerous, often lenticular, aquifer complexes. Given the objective of the present analysis, the first and the second aquifers are of highest significance. The first aquifer is characterized by shallow aeration zone waters and can be found on the surface in a form of a vast number of water-filled terrain depressions. It also includes numerous lakes located in the north east of the investigated area. Owing to the meliorations done in the past, the area is crisscrossed with drainage channels that are still filled with water. It is worth noting that the Quaternary-Upper Cretaceous stratum lacks Tertiary deposits, as the Tertiary age was totally reduced by the following intensive erosion. As a result, the Quaternary deposits reside directly on the eroded Upper Cretaceous. The results of

Table 2. Profile of Bogdanka BP-4

\begin{tabular}{|c|c|c|}
\hline Depth [m] & Lithology & Geologic period \\
\hline $0.00-0.80$ & Sandy soil & \multirow{6}{*}{ Quaternary } \\
\hline $0.80-2.80$ & Sandy clay & \\
\hline $2.80-16.00$ & Fine-grained sand & \\
\hline $16.00-32.00$ & Medium and coarse-grained sand & \\
\hline $32.00-35.50$ & Clay & \\
\hline $35.50-41.70$ & Vari-grained sand with pebbles & \\
\hline $41.70-150.00$ & Marl & \multirow{10}{*}{$\begin{array}{c}\text { Upper } \\
\text { Cretaceous }\end{array}$} \\
\hline $150.00-250.00$ & Chalky limestone & \\
\hline $250.00-300.00$ & Marly limestone & \\
\hline $300.00-350.00$ & Limestone with marly insertions. flint nodules at sill & \\
\hline $350.00-450.00$ & Chalky limestone with single concretions and flat flints & \\
\hline $450.00-550.00$ & Chalky limestone with frequent concretions of flints & \\
\hline $550.00-569.00$ & Chalky limestone & \\
\hline $569.00-576.00$ & Chalky limestone laminated by marly substance & \\
\hline $576.00-581.40$ & Sandy limestone. single concretions of phosphorites at sill & \\
\hline $581.40-582.00$ & Marly limestone with phosphorite concretions & \\
\hline $582.00-584.50$ & Glauconite sandstone with prosphorite concretions & Albian \\
\hline $584.50-587.00$ & Organodetritic limestone & \multirow{18}{*}{ Jurassic } \\
\hline $587.00-589.30$ & Oolitic limestone & \\
\hline $589.30-590.40$ & Detritic limestone & \\
\hline $590.40-596.20$ & Pelitic limestone & \\
\hline $596.20-603.00$ & Oolitic limestone & \\
\hline $603.00-607.90$ & Pseudo oolitic limestone with marly limestone insertions & \\
\hline $607.90-612.80$ & Pelitic limestone lustrated & \\
\hline $612.80-618.00$ & Oolitic limestone & \\
\hline $618.00-626.50$ & Pelitic limestone lustrated & \\
\hline $626.50-650.10$ & Pelitic limestone with marly limestone insertions. tectonically shattered $1 \mathrm{~m}$ in floor layer & \\
\hline $650.10-656.40$ & Detritic limestone with marly limestone insertions & \\
\hline $656.40-661.90$ & Organogenic limestone & \\
\hline $661.90-665.90$ & Cryptocrystalline limestone. cavernous in roof & \\
\hline $665.90-671.50$ & Reef limestone with much contents of clayey substance & \\
\hline $671.50-677.70$ & Organodetritic fine-crystalline limestone with numerous fauna. dolomite crumbs. single caverns & \\
\hline $677.70-678.90$ & Detritic limestone & \\
\hline $678.90-690.30$ & Brecciated limestone with flinty dolomite in floor & \\
\hline $690.30-700.30$ & Fine-crystalline limestone. with numerous flinty dolomite lens in roof & \\
\hline $700.30-703.20$ & Crystalline limestone. sandy & \multirow{2}{*}{ Westphalian } \\
\hline $703.20-703.80$ & Crystalline cavernous limestone. with marly films in roof & \\
\hline
\end{tabular}


long-standing observations of the quality of the Jurassic water show that the Cretaceous deposits which have an average thickness of $250 \mathrm{~m}$ with a vertical permeability coefficient amounting to $10^{-9} \mathrm{~m} / \mathrm{s}$ are practically impermeable. The layer arrangement is illustrated by means of over $500 \mathrm{~m}$

Table 3. Profile of Lublin 20

\begin{tabular}{|c|c|c|}
\hline Depth [m] & Lithology & Geologic period \\
\hline $0.00-0.30$ & Soil & \multirow{4}{*}{ Quaternary } \\
\hline $0.30-1.00$ & Fine-grained sand & \\
\hline $1.00-6.00$ & Clay & \\
\hline $6.00-48.00$ & Vari-grained sand & \\
\hline $48.00-265.00$ & Marl with chalk-similar limestone & \multirow{5}{*}{ Upper Cretaceous } \\
\hline $265.00-425.00$ & Chalky limestone with marly and brittle limestone insertions & \\
\hline $425.00-545.50$ & Chalky limestone with marly and brittle limestone insertions. also flints insertions & \\
\hline $545.50-567.80$ & Chalky limestone with brittle limestone insertions & \\
\hline $567.80-575.20$ & Sandy limestone with marl insertions & \\
\hline $575.20-577.40$ & Glauconitic limestone with phosphorite concretions & Albian \\
\hline $577.40-589.70$ & Limestone with numerous fauna and detritic limestones insertions & \multirow{8}{*}{ Jurassic } \\
\hline $589.70-608.40$ & Oolitic limestone with fauna & \\
\hline $608.40-658.00$ & Limestone with oolite andpelitic limestone concretions & \\
\hline $658.00-667.00$ & Zoogenic limenstone & \\
\hline $667.00-695.00$ & Nodular limestone. with thin sandstone insertions in part of floor & \\
\hline $695.00-696.80$ & Fine-grained sandstone with fauna & \\
\hline $696.80-698.20$ & Sandy limestone & \\
\hline $698.20-699.60$ & Vari-grained sandstone & \\
\hline $699.60-706.40$ & Claystone - sandy in roof & Westphalian \\
\hline
\end{tabular}

Table 4. Profile of Lublin 15

\begin{tabular}{|c|c|c|}
\hline Depth [m] & Lithology & Geologic period \\
\hline $0.00-0.30$ & Soil & \multirow{5}{*}{ Quaternary } \\
\hline $0.30-3.00$ & Dusty sand & \\
\hline $3.00-20.00$ & Fine-grained sand & \\
\hline $20.00-30.00$ & Clay & \\
\hline $30.00-60.00$ & Fine-grained sand & \\
\hline $60.00-80.00$ & Marl & \multirow{8}{*}{ Upper Cretaceous } \\
\hline $80.00-310.00$ & Marly limestone & \\
\hline $310.00-372.00$ & Chalky limestone & \\
\hline $372.00-580.00$ & Brittle limestone with flints concretions & \\
\hline $580.00-584.20$ & Chalky limestone with marl insertions & \\
\hline $584.20-594.60$ & Chalky limestone with marly limestone and marl insertions & \\
\hline $594.60-600.00$ & Sandy limestone - fromthe deep 598.90m single phosphorite concretions & \\
\hline $600.00-600.25$ & Marl & \\
\hline $600.25-603.40$ & Glauconitic sandstone with phosphorite concretions & Albian \\
\hline $603.40-605.50$ & Oolitic limestone & \multirow{11}{*}{ Jurassic } \\
\hline $605.50-611.40$ & Pelitic limestone with oolitic limestone insertions & \\
\hline $611.40-617.50$ & Oolitic limestone & \\
\hline $617.50-681.90$ & Pelitic oolitic limestone - passing to detritic limestone in floor & \\
\hline $681.90-687.90$ & Finecrystalline limestone. marl insertions & \\
\hline $687.90-697.40$ & Reef limestone with lignite crumbs & \\
\hline $697.40-709.40$ & Brecciated cavernous limestone & \\
\hline $709.40-711.80$ & Crystalline limestone & \\
\hline $711.80-719.20$ & Detritic sandy limestone with dolomite insertions & \\
\hline $719.20-723.60$ & Detritic limestone & \\
\hline $723.60-723.70$ & Sandstone & \\
\hline $723.70-725.80$ & Siltstone & Westphalian \\
\hline
\end{tabular}


deep boreholes that are representative of the area. These boreholes include: Bogdanka BP-4, Lublin 20, Lublin 15, Lublin 4, Lublin 19, Lublin 3, Lublin 5 (according to the Central Geological Database - Tables 2 to 8). Their locations are given in Figure 1.

The phenomenon of water descent to lower levels was not observed. In a situation like this, every natural or anthropogenic depression becomes filled up with water. The degree of height difference, together with the inflow of both rainwater and groundwater are the only factors that lead to permanent or temporary filling of the entire depression. Given the exposure of such reservoirs to seasonal changes, the variations in water quality parameters must be seasonal, too. The quality of surface water in the Lublin Coal Basin region is also significantly affected by increased tourism and recreation in the neighbouring ŁęczyńskoWłodawskie Lake District, as well as by farming activities such as growing crops and farming animals. The impact of farming with its periodic activity is particularly visible in the vicinity of the anthropogenic Nadrybie and Szczecin reservoirs.

Table 5. Profile of Lublin 4

\begin{tabular}{|c|c|c|}
\hline Depth [m] & Lithology & Geologic period \\
\hline $0.00-0.30$ & Soil & \multirow{5}{*}{ Quaternary } \\
\hline $0.30-2.50$ & Fine-grained sand & \\
\hline $2.50-25.00$ & Vari-grained sand & \\
\hline $25.00-50.00$ & Clay with quartz boulders $\phi 5 \mathrm{~mm}$ & \\
\hline $50.00-70.00$ & Vari-grained sand with boulders $\phi 5 \mathrm{~mm}$ & \\
\hline $70.00-360.00$ & Chalky limestone with marl insertions and marly limestones & \multirow{7}{*}{ Upper Cretaceous } \\
\hline $360.00-450.00$ & Chalky limestone with brittle limestone insertions & \\
\hline $450.00-540.00$ & Chalky limestone with brittle limestone and flints insertions & \\
\hline $540.00-570.00$ & Chalky limestone with greed-like and marly limestone insertions & \\
\hline $570.00-576.80$ & Chalky limestone with marly limestone insertions & \\
\hline $576.80-581.60$ & Chalky limestone with marl insertions & \\
\hline $581.60-589.30$ & Limestone with marl. sandy in floor & \\
\hline $589.30-590.00$ & Fine-grained glauconitic sandstone. phosphorite concretions in floor & Albian \\
\hline $590.00-640.00$ & Limestone. sandy in roof & \multirow{5}{*}{ Jurassic } \\
\hline $640.00-670.00$ & Pelitic limestone with brittle limestones insertions & \\
\hline $670.00-700.00$ & Limestone with brittle limestones insertions & \\
\hline $700.00-709.90$ & Sandy limestone with lumpy limestone. numerous fauna. cherts in roof & \\
\hline $709.90-714.00$ & Fine-grained limy sandstone & \\
\hline $714.00-716.10$ & Fine-grained micaceous sandstone with claystone insertions & Westphalian \\
\hline
\end{tabular}

Table 6. Profile of Lublin 19

\begin{tabular}{|c|c|c|}
\hline Depth [m] & Lithology & Geologic period \\
\hline $0.00-0.30$ & Soil & \multirow{4}{*}{ Quaternary } \\
\hline $0.30-2.00$ & Clay & \\
\hline $2.00-62.00$ & Vari-grained sand & \\
\hline $62.00-77.00$ & Sandy gravel with crumbs of marl & \\
\hline $77.00-276.00$ & Marl with creed-like limestone and writing chalk insertions & \multirow{5}{*}{ Upper Cretaceous } \\
\hline $276.00-367.00$ & Chalky limestone with brittle limestone and marl insertions & \\
\hline $367.00-562.00$ & Chalky limestone with flint insertions & \\
\hline $562.00-581.40$ & Chalky limestone with marl insertions & \\
\hline $581.40-587.10$ & Sandy limestone & \\
\hline $587.10-589.50$ & Fine-grained glauconitic sandstone with phosphorite insertions & Albian \\
\hline $589.50-690.00$ & Organodetritic limestone & \multirow{2}{*}{ Jurassic } \\
\hline $690.00-708.90$ & Pelitic sandy limestone with numerous fauna. nodules places & \\
\hline $708.90-711.10$ & Sandy claystone & Westphalian \\
\hline
\end{tabular}


Table 7. Profile of Lublin 3

\begin{tabular}{|c|c|c|}
\hline Depth [m] & Lithology & Geologic period \\
\hline $0.00-0.30$ & Soil & \multirow{3}{*}{ Quaternary } \\
\hline $0.30-2.00$ & Vari-grained sand & \\
\hline $2.00-52.00$ & Fine-grained sand & \\
\hline $52.00-72.00$ & Sandy marl & \multirow{7}{*}{ Upper Cretaceous } \\
\hline $72.00-282.00$ & Marl with writing chalk layers and creed-like limestone insertions & \\
\hline $282.00-453.50$ & Creed-like limestone with brittle limestone and marl insertions & \\
\hline $453.50-546.80$ & Creed-like limestone with flint insertions & \\
\hline $546.80-567.80$ & Sandy limestone with marl insertions & \\
\hline $567.80-579.70$ & Creed-like limestone withmarl insertions & \\
\hline $579.70-586.40$ & Sandy limestone & \\
\hline $586.40-586.80$ & Glauconiticsandstone with phosphorite in floor & Albian \\
\hline $586.80-680.00$ & Nodular pelitic limestone & \multirow{4}{*}{ Jurassic } \\
\hline $680.00-682.60$ & Pelitic limestone with numerous fauna & \\
\hline $582.60-695.80$ & Nodular limestone with numerous fauna & \\
\hline $695.80-708.10$ & Sandy limestone with pelitis limestone insertions & \\
\hline $708.10-724.90$ & Sandy claystone & Westphalian \\
\hline
\end{tabular}

Table 8. Profile of Lublin 5

\begin{tabular}{|c|c|c|}
\hline Depth [m] & Lithology & Geologic period \\
\hline $0.00-0.30$ & Soil & \multirow{3}{*}{ Quaternary } \\
\hline $0.30-2.00$ & Clay & \\
\hline $2.00-66.00$ & Vari-grained sand & \\
\hline $66.00-71.00$ & Marly clay & \multirow{7}{*}{ Upper Cretaceous } \\
\hline $71.00-190.00$ & Marl & \\
\hline $190.00-240.00$ & Creed-writing & \\
\hline $240.00-510.00$ & Limestone with Creed-writing and marly limestone insertions & \\
\hline $510.00-580.00$ & Limestone with flint insertions & \\
\hline $580.00-614.00$ & Chalky limestone & \\
\hline $614.00-620.50$ & Sandy limestone & \\
\hline $620.50-621.50$ & Sandstone with phosphorite concretions & Albian \\
\hline $621.50-705.00$ & Limestone with pelitic limestone insertions & \multirow{3}{*}{ Jurassic } \\
\hline $705.00-718.70$ & Sandy limestone with numerous fauna & \\
\hline $718.70-741.60$ & Nodular limestone with numerous fauna & \\
\hline $741.60-751.00$ & Claystone & Westphalian \\
\hline
\end{tabular}

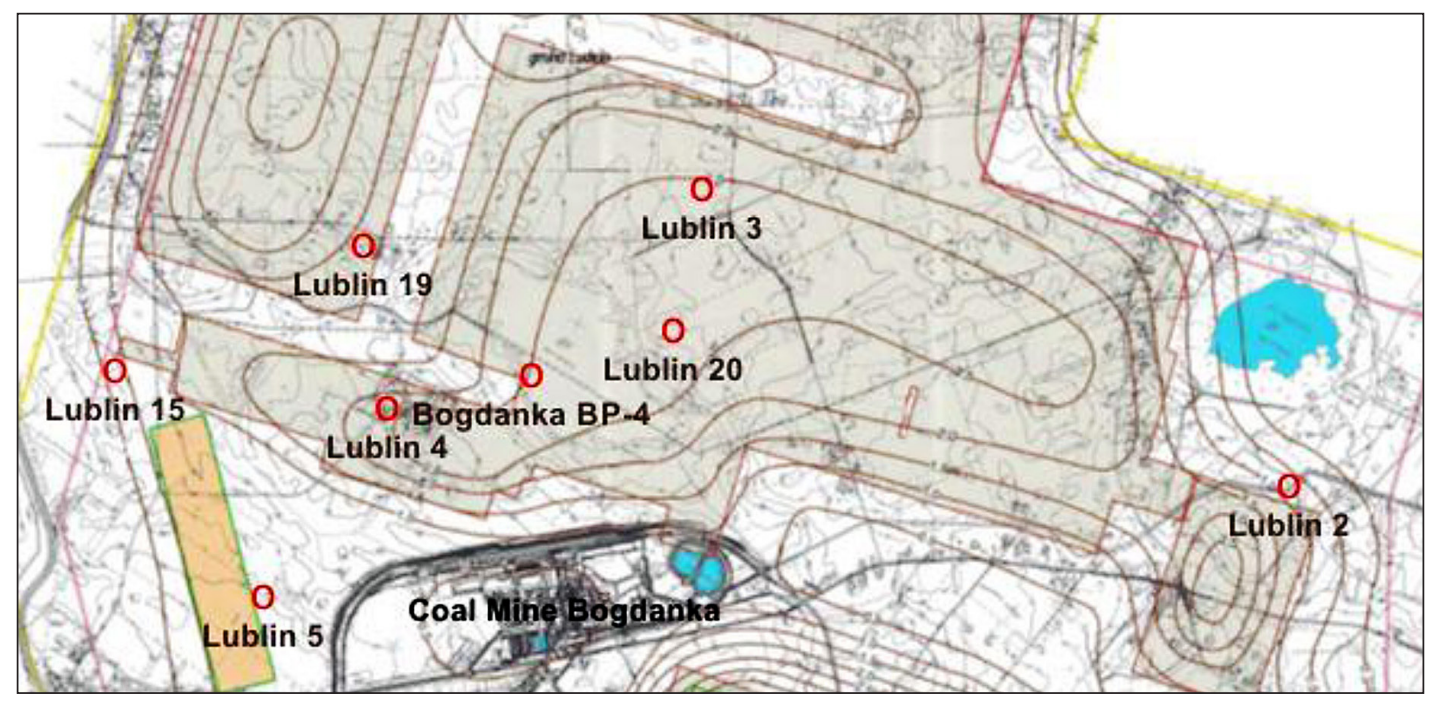

Figure 1. Location of representative boreholes 


\section{Description of the climate in the investigated area}

The climate in the Lublin Coal Basin region has features of continental climate. Summers and winters are of a similar length (an average summer is 105 days long while an average winter is 110 days long), short spring and autumn. Compared to other regions of Poland, this region has the most sunny days per year. This leads to heavy evaporation. The rainfall is usually irregular and it is the heaviest in summer, being approximately $40 \%$ of the total annual rainfall. The mean annual air temperature is $7.3^{\circ} \mathrm{C}$. The highest temperature, $+36.2^{\circ} \mathrm{C}$, was recorded in July 1959 , while the lowest, -34.2 , was recorded in January 1987 . The Marine polar air predominantly comes from the West and West-North.

\section{NATURAL ENVIRONMENT PRIOR TO MINING}

The Lublin Upland, with the Lublin Coal Basin located in its centre, has one of the most valuable natural environments in Poland. Natural objects possessing particular significance for cognitive, scientific and recreational reasons have been granted legal protection as the Poleski National Park, landscape parks, sanctuaries, Natura 2000 sites, ecological corridors and natural monuments. Some of them were established along with the onset of hard coal exploitation in Bogdanka. Some of these sites are located only a few kilometers away from the mining zones.
The stroke technology consists in leaving the empty space after mineral extraction unfilled. A natural consequence of this is that a depression starts to form above the post-mining void. Prior to the onset of mining, the investigated area was a flatland with low-density housing. Unsuitable for housing construction due to a high level of groundwater (even up to one meter below the surface), the area was used for making hay and for grazing farm animals. Given the lack of strong industrial anthropopressure, the flora and fauna of the area was hardly changed. Being a part of the Łęczyńsko-Włodawskie Lake District, this area quickly became popular with tourists. It was also used as a site for environmental research and observations, the results of which later served as the basis of documents for granting legal protection to this unique and valuable area.

\section{DEVELOPMENT OF BASIN SUBSIDENCE}

Intensive hard coal mining in three mines (Bogdanka, Nadrybie, Stefanów) located in the investigated area marked by the borders of the Lublin Coal Basin leads to terrain subsidence over the voids left after mineral extraction. The process is not rapid owing to vast spaces and the slow rate of subsidence of platform-arranged geologic layers. The results of the observations of water quality parameters in the first and subsequent aquifers reveal that the subsidence process is plastic; there are no cracks or faults. If they occurred, they would enable hydraulic connec-

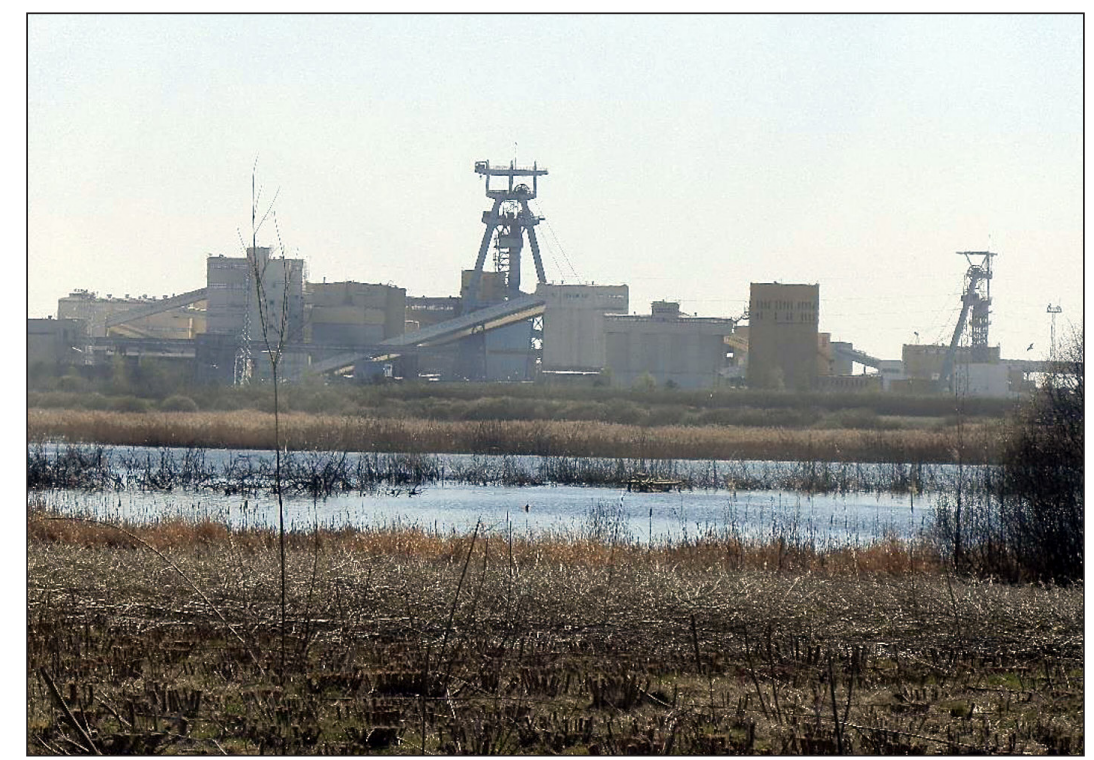

Photo 1. Inundated area in the village of Szczecin (photo by M. Ciosmak) 
tion between aquifers. The hydraulic connection would be easy to notice due to changes in water quality parameters. This, however, has not been observed. The results of geodetic measurement and visual observation clearly indicate subsidence. This gradual process is confirmed by the presence of inundated areas which occur in spring months when the snow melts or after heavy rainfalls. Gradually deprived of water via evaporation, the inundated areas become more and more extensive, and they do not have a clearly marked shoreline. The subsidence will continue as long as there are voids in mining activity zones. It is predicted that the process will continue for several years until the shoreline becomes stabilized. At its deepest part, the inundated area is currently 2-3 m deep under free water surface. However, the depth is not ultimate, as the process of subsidence can still be observed.

At present, there are two inundated areas in the vicinity of the Puchaczów V mining zone. The biggest one is the investigated anthropogenic water reservoir "Szczecin." Named after the nearby village, this reservoir has an area of ca. 90ha. Another water reservoir called "Nadrybie Reservoir" has an area of 30 ha and is located in the vicinity of the coal mine in Nadrybie.

Since basin subsidence is classified as mining damage, it is therefore regulated under relevant legal measures concerning land reclamation and development in order to prevent environmental changes caused by intensive underground hard coal mining. For this reason, it was decided that the shoreline of the "Szczecin" reservoir would be suitably shaped. According to Sawicki and Łyszczarz (2009), this indundated area is to be developed for recreational and retention purposes. The formation of the "Szczecin" reservoir cannot, however, be left to natural processes only, despite the predictions saying that the subsidence will proceed steadily in terms of time and geometry. Both the monitoring of this water reservoir and the observations of the older "Nadrybie Reservoir" included in the Natura 2000 network of sites demonstrate that the process must be controlled. Given the platform arrangement of layers that are parallel to one another and to terrain surface, it is therefore justified to create a subsidence model for every overlying layer. This can be done in an analogous way to the case of the "Nadrybie Reservoir," where the shoreline gradually becomes stabilized and the geologic profile (Table 9).

\section{ENVIRONMENTAL CHANGES}

The results of the observations reveal that the water-filled "Szczecin" reservoir begins to undergo changes that are similar to those characterizing the inundated area in the village of Nadrybie. Currently, the water is shallow and undergoing intensive euthrofication. It can be observed that the water table increases, thus flooding the surrounding grounds. In effect, the existing meadow plants get flooded and cease to grow. In places where the rate of subsidence is slower, we can observe the occurrence of coastline vegetation such

Table 9. Profile of Lublin 2 (Nadrybie Skrzyżowanie)

\begin{tabular}{|c|c|c|}
\hline Depth [m] & Lithology & Geologic period \\
\hline $0.00-1.50$ & Fine-grained sand & \multirow{4}{*}{ Quaternary } \\
\hline $1.50-5.00$ & Clay & \\
\hline $5.00-20.00$ & Vari-grained sand & \\
\hline $20.00-50.00$ & Fine-grained sand & \\
\hline $50.00-80.00$ & Marl & \multirow{5}{*}{ Upper Cretaceous } \\
\hline $80.00-500.00$ & Limestone with marly limestone insertions & \\
\hline $500.00-545.00$ & Sandy pelitic limestone & \\
\hline $545.00-562.00$ & Chalky limestone & \\
\hline $562.00-567.90$ & Limestone with fauna & \\
\hline $567.90-569.20$ & Sandstone & Albian \\
\hline $569.20-574.00$ & Limestone with oolitic limestone insertions & \multirow{5}{*}{ Jurassic } \\
\hline $574.00-667.00$ & Limestone & \\
\hline $667.00-683.40$ & Limestone with organodetritic limestone and flint insertions & \\
\hline $683.40-685.30$ & Sandy limestone with sandstone insertions & \\
\hline $685.30-689.00$ & Fine-graines sandstone, $1,0 \mathrm{~m}$ limestone in the middle part of layer & \\
\hline $689.00-700.70$ & Claystone $0,05 \mathrm{~m}$ carbonaceous in floor & $\begin{array}{c}\text { Upper Carboniferous, } \\
\text { Westphalian }\end{array}$ \\
\hline
\end{tabular}




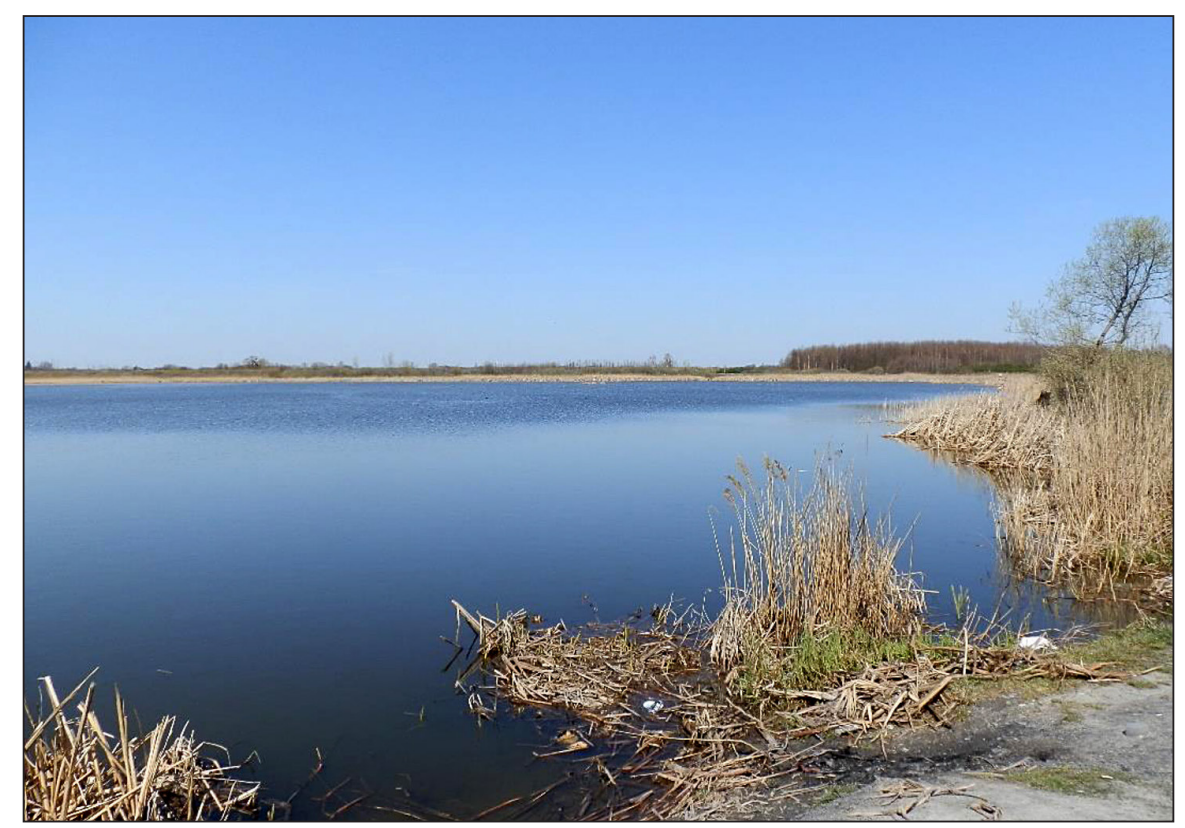

Photo 2. "Nadrybie Reservoir" which makes part of the Natura 2000 network (photo by M.Ciosmak)

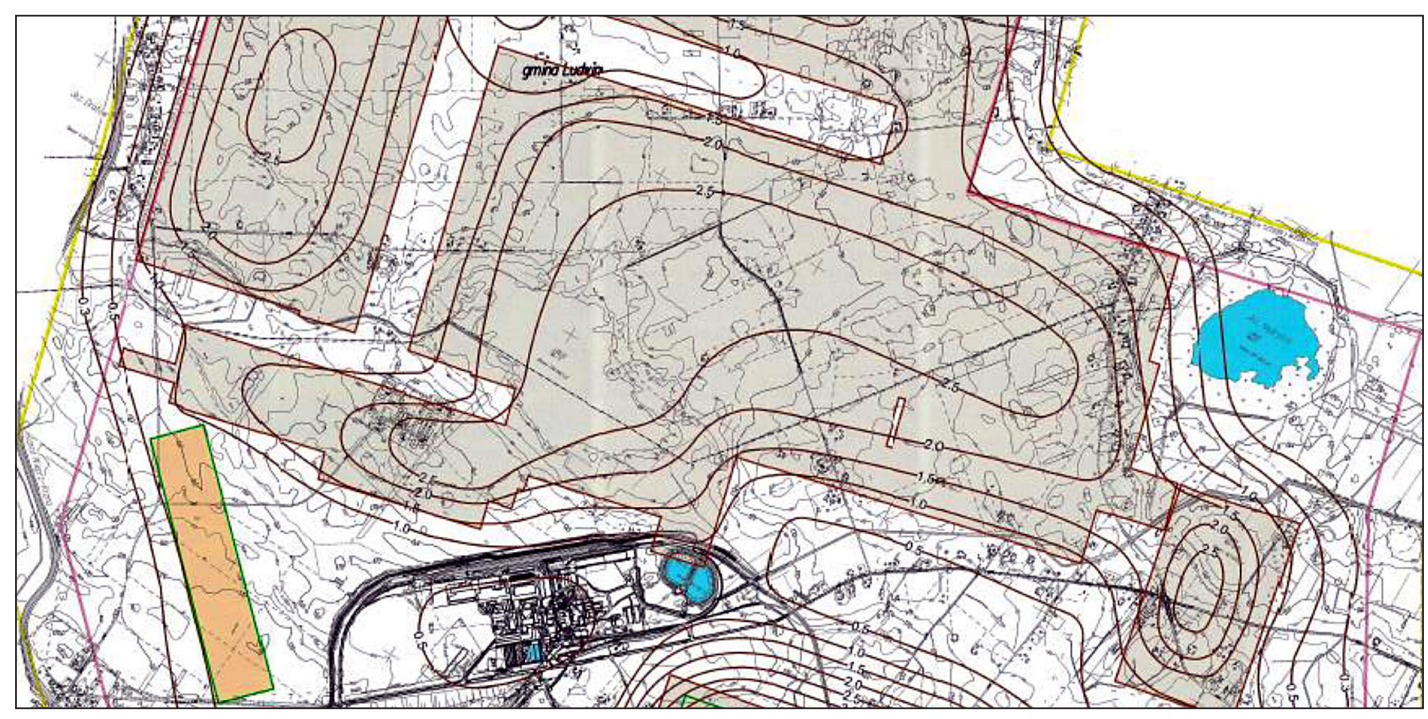

Figure 2. Areas of the predicted subsidence due to large-scale exploitation of hard coal

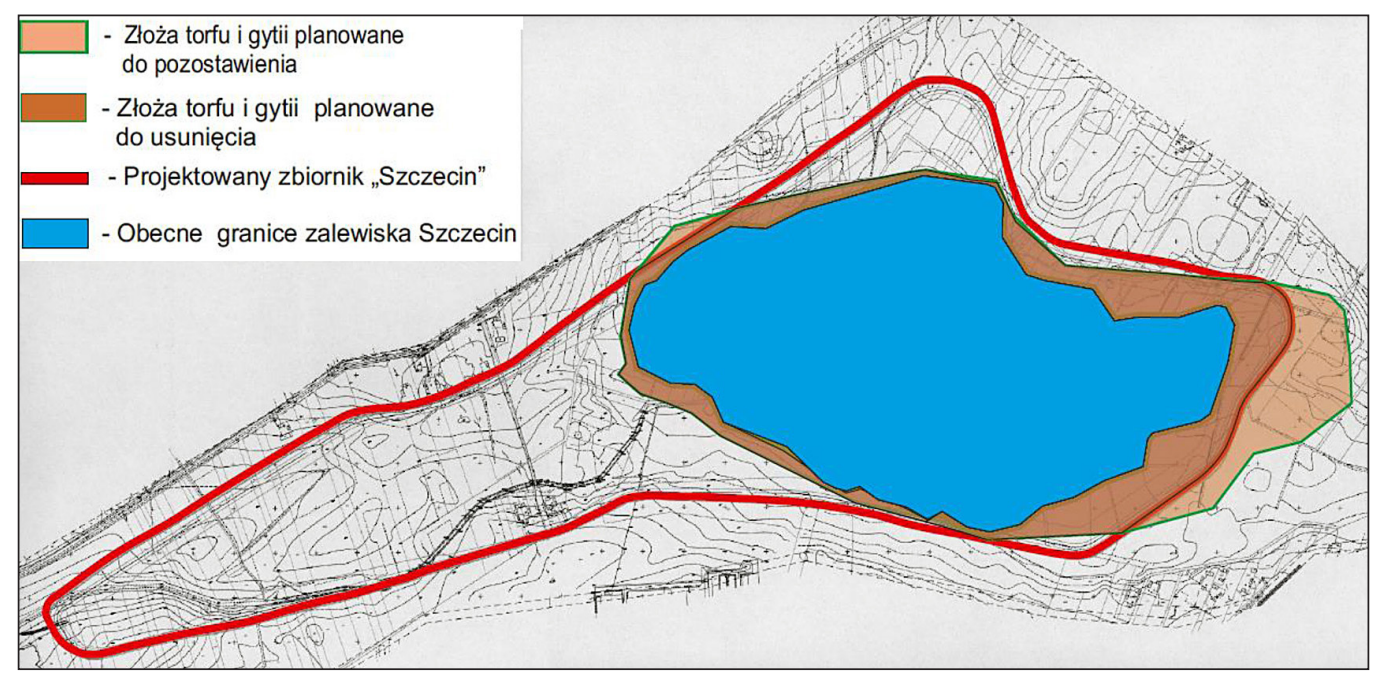

Figure 3. Location and designed shoreline shape of the "Szczecin" reservoir 
as reed, bulrush, and reed mace, as well as aquatic plants. The shores of thereby enlarged Lake District area slowly become inhabited by waterfowl for nesting. Residing some 100 meters away from the current unstabilized shoreline, the local population restocks this area of water for fishing purposes. Due to intensive evaporation, the enlarging water reservoir creates a characteristic microclimate, which is particularly perceptible during periods of high air temperatures. The changes will also affect the landscape, as the formation of the water reservoir will add to its picturesqueness. Considering the changes that can occur after the ultimate formation of the "Szczecin" reservoir, it should be stressed that the lithological aspects, particularly the high layer thickness (amounting to several hundred meters) of carbonate formations, give basis for claiming that the mean vertical permeability coefficient of these formations and slow plastic subsidence above voids will not create hydraulic connection between the surface and the strata located below.

\section{PREDICTED DEVELOPMENT OF THE "SZCZECIN" RESERVOIR}

According to the technical design, the anthropogenic water reservoir "Szczecin" will have a target surface area of 200 ha and will be included in the Wieprz-Krzna Channel hydrologic system. Given the basin's recreational function (fishing), the design inlcudes technical solutions for shoreline determination and water table stabilization (Figure 3). An interesting aspect of the design is the predicted use of mining wastes such as gangue for island formation and retrenchment. In the Lublin Coal Basin, 30\% of gangue is processed into building elements. The island will provide a safe place for birds to hatch eggs. It is highly probable that the newly created "lake" will play a similar role to that of the "Nadrybie" reservoir, which is included in the Natura 2000 network as a nature conservation site.

\section{MODEL OF DEVELOPMENT OF THE "SZCZECIN" RESERVOIR AND ITS SURROUNDINGS}

The formation of water-filled subsidence is an irreversible process caused by the applied mining technology. Therefore, it is necessary to develop this water reservoir once its bottom and shoreline become stabilized or to modify it by erecting a hydrotechnical construction. Figure 4 shows a schematic model of procedure implemented after the first symptoms of terrain subsidence above post-mining voids.

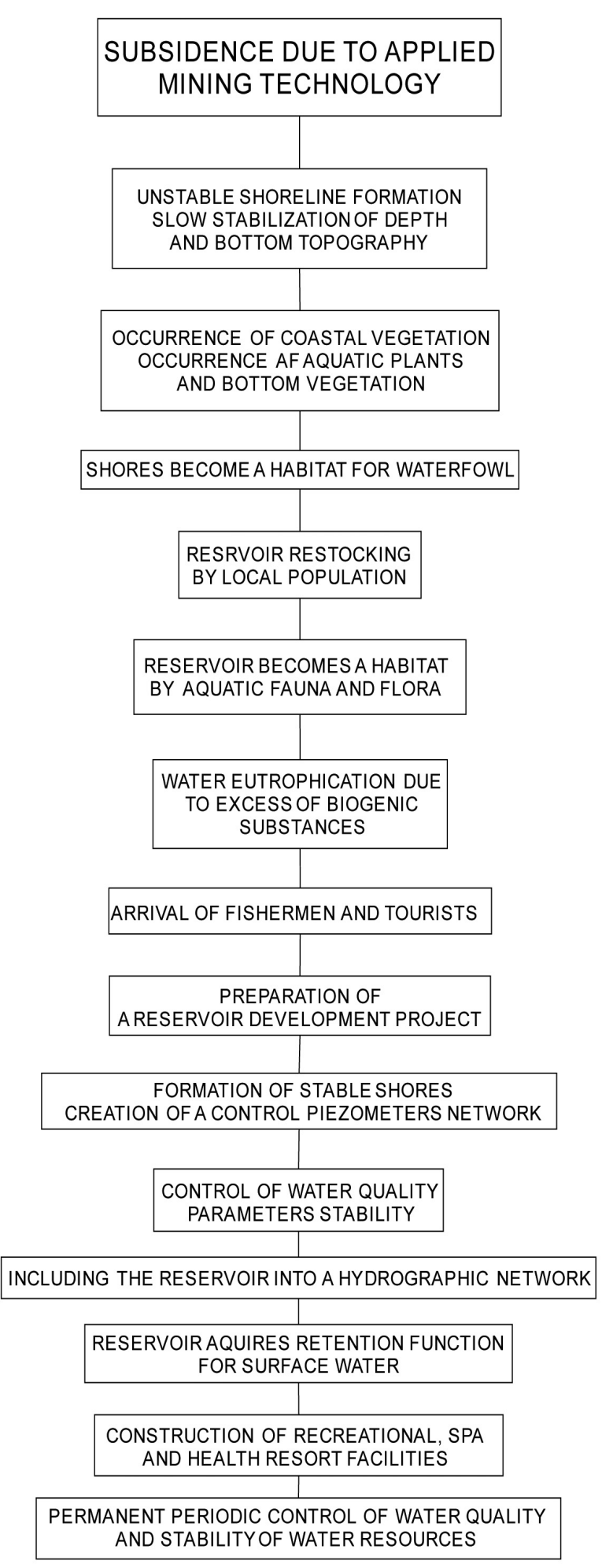

Figure 4. Schematic model of development of the anthropogenic water reservoir "Szczecin" (by Author) 


\section{CONCLUSIONS}

The anthropogenic water reservoir "Szczecin" is the second important inundated area in the vicinity of the Hard Coal Mine "Bogdanka". It is created by the environment as a result of the applied stroke technology for coal mining, which consists in leaving voids after mineral extraction unfilled. The depressions which occur several years following extraction from the exploited Carboniferous strata are quickly filled with surface and rainwater. Despite intensive water evaporation in summer months, the loss of water in the reservoir is less and less noticeable, due to a gradual enlargement of the reservoir's capacity. The redressing of mining damage means reducing its effect on the environment. The process of basin subsidence is irreversible, thus the development of the water reservoir should be made in the least burdensome way; if possible, the newly created "lake" should be used for tourist and recreational purposes. The Lublin Coal Basin and the anthropogenic water reservoir "Szczecin" are located in a region that abounds in nature conservation sites, including the Poleski National Park, landscape parks, ecological corridors, nature reserves and natural monuments, as well as Natura 2000 sites. Hence, it is justified that the water reservoir and its surrounding area be developed and adapted to recreational purposes. Water from the Jurassic deposits contains a stable concentration of fluorine ions of even up to $10 \mathrm{mg} / 1$, which is considered therapeutic.

\section{REFERENCES}

1. Dobrowolski R, Harasimiuk M., BrzezińskaWójcik T. 2014. Structural Controlof the Reliefin the Lublin Upland and Roztocze Region. Przegląd Geologiczny, 62(1), 51-62.

2. Documents from Archive of Coal Mine "Bogdanka".

3. Sawicki B., Łyszczarz L. 2009. Zagospodarowanie turystyczne i rekeracyjne jako szansa rozwoju dla terenów zdegradowanych obszaru górniczego kopalni węgla w Bogdance. Inżynieria Ekologiczna-Ecological Engineering, 2, 121-130.

4. Fan G., Zhang D. 2015. Mechanisms of aquifer protection in underground coal mining. Mine Water Environment 34-95-104, Springer.

5. Kazimierski B., Gidziński T. 2011. Conception of reorganization of national observation-research groundwater monitoring network. Biuletyn Państwowego Instytutu Geologicznego, No. 445, 255-266.

6. Machowski R. 2010. Przemiany geosystemów zbiorników wodnych powstałych w nieckach osiadania na Wyzynie Katowickiej. Wydawnictwo Uniwersytetu Śląskiego, Katowice.

7. Michalczyk Z., Zarębski K. 1995. Ground Water Interchange in the South-Western Part of the Łęczna-Włodawa Lake Region in "Bogdanka" Colliery .Kraków-Krynica. Współczesne problemy hydrogeologii, T. VII, 119-126.

8. Molenda T. 2015. Changes in the morphometry of fishing breeding ponds under the influence of mining subsidence. Inżynieria Ekologiczna-Ecological Engineering, 42, 36-41. 